\title{
Assessment of Supply Chain Agility to Foster Sustainability: Fuzzy-DSS for a Saudi Manufacturing Organization
}

\author{
Ateekh Ur Rehman ${ }^{1, *(D)}$, Ayoub Al-Zabidi ${ }^{1}$, Mohammed AlKahtani ${ }^{1}{ }^{\circledR}$, Usama Umer $^{2}{ }^{\circledR}$ and \\ Yusuf Siraj Usmani ${ }^{1}$ \\ 1 Department of Industrial Engineering, College of Engineering, King Saud University, Riyadh 11421, \\ Saudi Arabia; alzabidi_8@hotmail.com (A.A.-Z.); moalkahtani@ksu.edu.sa (M.A.); \\ yusmani@ksu.edu.sa (Y.S.U.) \\ 2 Advanced Manufacturing Institute, King Saud University, Riyadh 11421, Saudi Arabia; uumer@ksu.edu.sa \\ * Correspondence: arehman@ksu.edu.sa
}

Received: 15 April 2020; Accepted: 9 May 2020; Published: 13 May 2020

\begin{abstract}
Supply chain agility and sustainability is an essential element for the long-term survival and success of a manufacturing organization. Agility is an organization's ability to respond rapidly to customers' dynamic demands and volatile market changes. In a dynamic business environment, manufacturing firms demand agility to be evaluated to support any alarming decision. Sustainability is an aspect to sustain collaboration, value creation, and survival of firms under a dynamic competitive business scenario. Agility is a capability that drives competitiveness to foster sustainability aspects. The purpose of this article is to consider and evaluate the supply chain behavior within the context of Saudi enterprises. The efficacy and relevance of this model were explored through a case study conducted in a Saudi dairy manufacturing corporation. Owing to the complexity and a large number of calculations that are required for evaluating the agility of the supply chain, a decision support system was proposed as a tool to assess the supply chain and identifying barriers to a strategic sustainable solution for a specific organizational target. The decision support system is extensive as it contains six separate agility enablers and ninety-three agility attributes for the supply chain. The assessment was carried out using a fuzzy multi-criteria method. It combines the performance rating and importance weight of each agile supply chain-enabler-attribute. To achieve and sustain local and global success, the case organization strove to become a major local and global manufacturer to satisfy its customers, reduce its time to market, lower its total ownership costs, and boost its overall competitiveness through improving its agility across supply chain activities to foster sustainability for a manufacturing organization located in Saudi Arabia.
\end{abstract}

Keywords: supply chain management; agility; sustainability; fuzzy approach

\section{Introduction}

Multi-criteria fuzzy-based modeling of supply chains is a powerful way to increase the understanding of the behavior of supply chains. Such modeling supports decision makers in developing a sustainable strategic solution for a specific organizational problem [1,2]. From the literature, it is obvious that the authors have established a variety of techniques for assessing the efficiency of the supply chain. However, these measures are subjectively defined by linguistic terms which can often be challenged for the shortcomings of the scale used to rate the supply chain's prowess [3,4]. Industries have recognized that resilience is important to their continued survival and productivity within their supply chain. The concerns to be addressed when integrating agility within a 
supply chain are agility and its assessment, degree, and hindrances [5-7]. A decision support system (DSS) is regarded as a computer-based model that encompasses a collection of data processing protocols and assumptions to help an administrator make a judgment [8-10]. It is an immersive computer-based framework designed to help policy makers use communications technology, data, records, knowledge, and/or models to recognize as well as overcome problems and to make choices [11].

Currently, computer-based modeling is a required part of DSSs in many areas of business and engineering. It is evident from the literature that computer-based modeling is also essential and required in the support of decision makers for assessing the supply chain [12-14]. Tolone [15] indicated that a DSS would be built in the future to perform the calculations for evaluating the supply chain. As a result of DSS, the decision makers will be able to accurately acquire information for assessing the comprehensive agility and limitations within the supply chain $[14,16]$.

This paper is one of the first studies to investigate many different questions, in context to the Saudi Arabian manufacturing organization, including 'What is the meaning of agility and how can organization measure it?', 'How can the organization get a benefit from measuring agility to sustain and compete in an ever-changing dynamic demand market?'. As a result, the objective is set to an interactive computer-based fuzzy-DSS approach for a Saudi manufacturing organization.

A set of graphical user interfaces (GUIs), database, modeling, data analysis, and programming tools, a macro language, and visual basic for applications (VBA) together with add-in programs were adopted to develop a useful multi-criteria fuzzy logic approach-based DSS [9,17]. The proposed fuzzy DSS model is designed to build customer-friendly GUIs, stand-alone phase-by-phase tutorials, and valuable security features, including password protection and user data monitoring functionalities.

This paper includes six sections. Section 2 briefly reviews and presents different important capabilities, enablers, and attributes of supply chain agility evaluation. Subsequent Sections 3 and 4 present the case study and the proposed fuzzy-DSS evaluation approach for the case organization, respectively. Section 5 presents the discussion and the main findings and implications of the study. Lastly, Section 6 concludes with future research of the study.

\section{Multi-Criteria Fuzzy Approach: Capabilities, Enablers, Attributes of a Supply Chain}

A multidisciplinary analysis of prior agility studies has been performed to clarify supply chain agility, considering the complex and multifaceted aspect of supply chain management. While each of the definitions of the supply chain agility highlights distinct issues, there are aspects of the supply chain agility relevant for all interpretations (see Table 1). In Table 1, sustainable supply chain agility dimensions are summarized as organizational, strategic, commitment, informative, customer sensitivity, and human competence. Such dimensions allow more versatility in the supply chain for production/service establishments. Supply chain agility enablers are used to define the overall agility capabilities, which are responsiveness, competency, flexibility, and quickness to be sustainable $[4,18]$.

Table 1. Sustainable supply chain agility definitions and dimensions.

\begin{tabular}{|c|c|c|c|c|c|c|c|}
\hline \multirow{2}{*}{ References } & \multirow{2}{*}{ Sustainable Supply Chain Agility Definitions } & \multicolumn{6}{|c|}{ Dimensions \# } \\
\hline & & 1 & 2 & 3 & 4 & 5 & 6 \\
\hline [19] & $\begin{array}{l}\text { The ability of an organization to respond rapidly to changes in } \\
\text { demand, both in terms of volume and variety. }\end{array}$ & $\sqrt{ }$ & $\sqrt{ }$ & $\sqrt{ }$ & & $\sqrt{ }$ & \\
\hline$[14,15]$ & $\begin{array}{l}\text { Effectively integrating the supply chain and forging close and } \\
\text { long-term relationships with customers and suppliers. }\end{array}$ & & & $\sqrt{ }$ & $\sqrt{ }$ & $\sqrt{ }$ & $\sqrt{ }$ \\
\hline [20] & $\begin{array}{l}\text { Is all about customer responsiveness and market turbulence and } \\
\text { requires specific capabilities. }\end{array}$ & $\sqrt{ }$ & $\sqrt{ }$ & & $\sqrt{ }$ & $\sqrt{ }$ & $\sqrt{ }$ \\
\hline$[17,18,21,22]$ & $\begin{array}{l}\text { An ability to have a visibility of demand, flexible and quick } \\
\text { response, and synchronized operations. }\end{array}$ & $\sqrt{ }$ & $\sqrt{ }$ & $\sqrt{ }$ & & $\sqrt{ }$ & \\
\hline
\end{tabular}


Table 1. Cont.

\begin{tabular}{|c|c|c|c|c|c|c|c|}
\hline \multirow{2}{*}{ References } & \multirow{2}{*}{ Sustainable Supply Chain Agility Definitions } & \multicolumn{6}{|c|}{ Dimensions \# } \\
\hline & & 1 & 2 & 3 & 4 & 5 & 6 \\
\hline [23-25] & $\begin{array}{l}\text { An effective flexibility and quality management to reduce waste } \\
\text { and avoid customer dissatisfaction. It also requires product and } \\
\text { service differentiation strategies, as well as performance } \\
\text { measures of product quality, innovation, and innovation, all } \\
\text { geared toward flexibility and lead time reduction. }\end{array}$ & $\sqrt{ }$ & $\sqrt{ }$ & & $\sqrt{ }$ & $\sqrt{ }$ & $\sqrt{ }$ \\
\hline$[26,27]$ & $\begin{array}{l}\text { Have both hard and soft criteria, such as flexibility, profitability, } \\
\text { quality, innovativeness, and proactive in response to cost, speed, } \\
\text { and robustness. }\end{array}$ & $\sqrt{ }$ & $\sqrt{ }$ & $\sqrt{ }$ & $\sqrt{ }$ & $\sqrt{ }$ & $\sqrt{ }$ \\
\hline [28-31] & $\begin{array}{l}\text { Initiative that is needed to provide superior value and to manage } \\
\text { disruption risks and guarantee uninterrupted service } \\
\text { provisioning. Agility is required for both risk mitigation and } \\
\text { rapid response. }\end{array}$ & $\sqrt{ }$ & $\sqrt{ }$ & & & & \\
\hline [12] & $\begin{array}{l}\text { Evolve products and services quickly and economically in } \\
\text { response to the customers' dynamic demands. }\end{array}$ & $\sqrt{ }$ & $\sqrt{ }$ & $\sqrt{ }$ & $\sqrt{ }$ & $\sqrt{ }$ & $\sqrt{ }$ \\
\hline [32] & $\begin{array}{l}\text { An operational strategy focused on inducing velocity and } \\
\text { flexibility in the supply chain to satisfy customer needs. }\end{array}$ & $\sqrt{ }$ & $\sqrt{ }$ & $\sqrt{ }$ & & $\sqrt{ }$ & $\sqrt{ }$ \\
\hline [33] & $\begin{array}{l}\text { Dynamic alliance of member companies, the formation of which } \\
\text { is likely needed to change frequently in response to } \\
\text { fast-changing markets. }\end{array}$ & $\sqrt{ }$ & $\sqrt{ }$ & $\sqrt{ }$ & $\sqrt{ }$ & $\sqrt{ }$ & \\
\hline [29] & $\begin{array}{l}\text { The ability of a supply chain to react quickly to market changes } \\
\text { and customer needs. }\end{array}$ & & & $\sqrt{ }$ & $\sqrt{ }$ & $\sqrt{ }$ & $\sqrt{ }$ \\
\hline
\end{tabular}

\# Dimensions: 1: organizational; 2: strategic; 3: commitment; 4: informative; 5: customer sensitivity; 6: human competence.

In the present knowledge-rich business environment, managerial practices are required that enable the exploration of a competitive base and sustainable strategies to be successful in a changing volatile market environment [34].

For any supply chain agility is an ability to provide customer-driven products and services and overcome unexpected challenges in logistic and distribution systems [35], taking advantage of changes as opportunities arise, and to survive and sustain the unexpected threats from a dynamic and volatile business environment [6,9]. In implementing agility in a supply chain, the issues to be examined are agility measurement, levels, and barriers $[6,36]$. The assessment of agility in supply chains is quite important as it is an indicator of the strategic sustainability position [37,38].

Initially, authors $[1,9,36,39-44]$ evaluated supply chain agility statistically through a questionnaireand interview-based data collection approach. Their goal was to identify trends and present the important attributes of agile supply chains for the purpose of evaluating agility.

Subsequently, authors [45-47] integrated the questionnaire data and analytical hierarchy process to measure agility. Their goal was to rank supply chain performance enablers based on the statistical information collected from industrial experts. The integration of the analytical hierarchy process with quality function deployment, structural modeling, fuzzy analysis, and performance value analysis is also adopted to assess a supply chain $[45,46,48]$. Numerous authors have used fuzzy logic to assess a supply chain. For example, authors $[33,37,49]$ used a multi-criteria fuzzy approach for agile supply chain evaluation, whereas another set of authors [50,51] used the fuzzy-topsis approach. Other authors adopted the generalized trapezoidal fuzzy approach [52,53], fuzzy data envelopment [54,55], fuzzy set theory [56,57], fuzzy intelligent agent-based approach [26], and fuzzy quality function deployment [58] to assess the agile supply chain. In addition, authors [36,53,59-66] integrated supply chain performance enablers (such as production, market, people, and information infrastructures) and their respective criteria to compute an agility index, whereas [64] suggested an approach in which performance enablers 
such as management responsibility, workforce, technology, and manufacturing strategies are adopted to compute an agility index. In addition, authors [57,67] presented a decision analysis tool for supply chain performance quantification.

Based on the literature review of multi-criteria assessment approaches for supply chain agility, the fuzzy logic approach is preferred herewith because of its ability to handle vague and uncertain situations as compared to other approaches [68]. Fuzzy logic provides an effective means of dealing with problems involving impreciseness and vagueness phenomena. In addition, some of these approaches convert problems into complex mathematical equations that are very difficult to solve by industrial experts. Multi-criteria fuzzy-DSS is a powerful way to increase the understanding of supply chain behavior. Such a DSS can support decision makers in developing a strategic solution for a specific organizational problem [69]. From the literature it is evident that authors have addressed a number of techniques to measure supply chain performance [33]. However, these measurements are described subjectively by linguistic terms that can always be criticized because of the limitations of the scales used to score the supply chain capabilities [33]. Saudi companies have realized that agility in their supply chain is essential for their sustainable survival and competitiveness.

\section{Case at Hand}

The organization is one of the largest manufacturers and distributors in the Middle East, with unique regional coverage and a market capitalization of more than $\$ 12.5$ billion. It supplies its fresh products to more than 110,000 retail outlets across Gulf Cooperation Council (GCC) countries, Egypt, and Jordan. In recent years, the organization has taken on a new international dimension, entering new territories, and investing in farmland in the Americas and Europe.

When product markets matured during the past two decades, large multinational firms endeavored to simultaneously provide local responsiveness and global integration in response to an uncertain business environment. Furthermore, due to increasing dynamic customer requirements, companies found it increasingly difficult to sustain, ensure, and achieve growth and success. These changes presented the case organization with significant challenges. To achieve and sustain local and global success, the case organization strove to become a major local and global manufacturer to satisfy its customers, reduce its time to market, lower its total ownership costs, and boost its overall competitiveness through improving its agility across supply chain activities. To improve the effectiveness of agile supply chain activities, the current study was carried out. The case on hand is to study and evaluate supply chain agility to foster sustainability for a manufacturing organization located in Saudi Arabia. The details of the proposed approach and its application are presented in the following sections and subsections.

\section{Assessment Model: Multi-Criteria Fuzzy Approach}

The objective of this paper is to investigate and measure different capabilities, enablers, and attributes that an organization targets in order to sustain and compete in agility in an ever-changing dynamic demand market. As a result, the objective is set to use multi-criteria fuzzy approach for a Saudi manufacturing organization for evaluating the agility of their supply chain. Subsequently, owing to the complexity and a large number of calculations that are required for evaluating the agility of the supply chain, a computer-based decision support system was proposed as a tool to assess the supply chain and identifying barriers to a strategic sustainable solution for a specific organizational target. The details of the adopted technical methodology and computer-based interactive fuzzy-DSS response and assessment tool for the specific origination as case study is presented in the following subsections. The list of variables used in the model is as follows: 


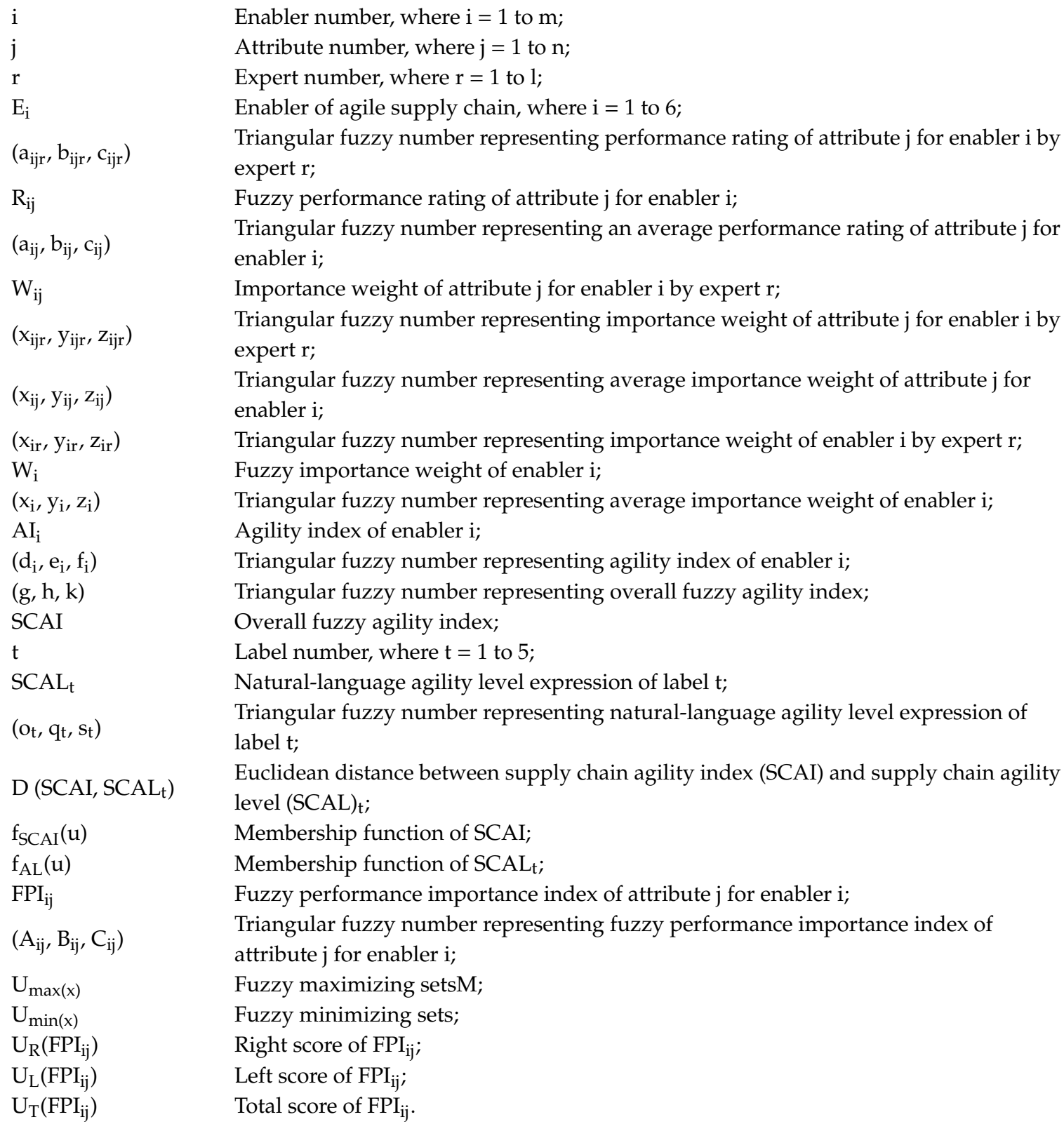

\subsection{Multi-Criteria Fuzzy Methodology}

The proposed stepwise methodology to evaluate supply chain agility includes an agility capabilities, enablers, and attributes identification scheme, information, and data flow, and determination of barriers and agility level (see Figure 1), each of which is illustrated stepwise below.

Step 1: Identification of agility capabilities, enablers, and attributes. The assessors in the organization must examine challenges in the business supply chain environment and identify performance evaluation criteria. Thus, the case organization's 4 capabilities, 6 enablers, and 93 attributes are identified and listed in Table 2.

Step 2: Demarcation of assessment scale and fuzzy numbers. After identifying agility capabilities, enablers, and attributes (Step 1), the agility assessment scale is demarcated using fuzzy logic through linguistic assessment and translation, as shown in Table 3 [70]. 


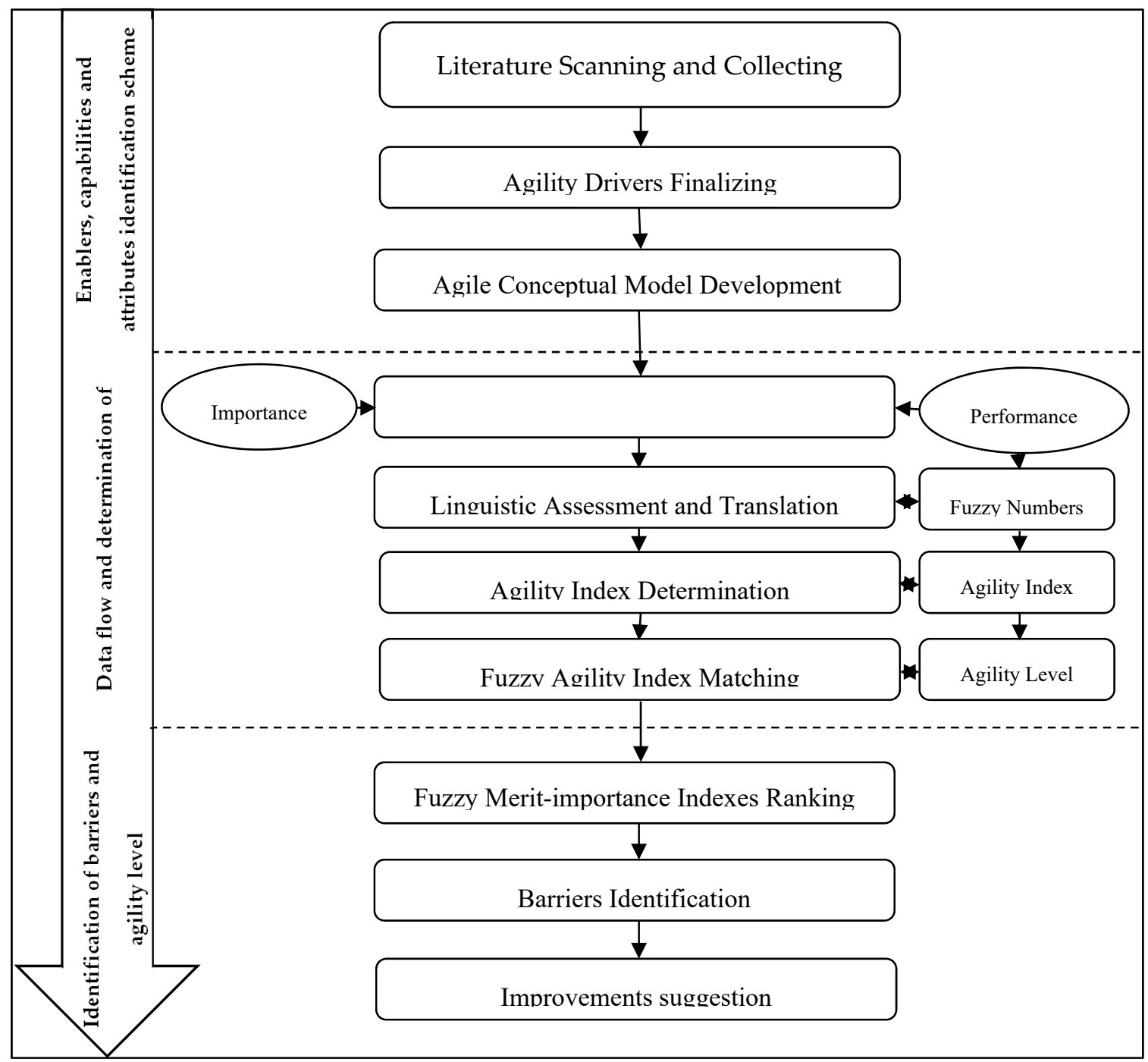

Figure 1. Methodology for evaluating supply chain agility.

Step 3: Determination of fuzzy weights and fuzzy performance ratings. The fuzzy performance ratings $R_{i j}$ and weights $W_{i j}$ for each attribute $j$ for a given enabler $i$ are calculated using Equations (1) and (2) $[50,71]$, respectively.

$$
\begin{gathered}
\mathrm{R}_{\mathrm{ij}} \equiv\left(\frac{\sum_{\mathrm{r}=1}^{1} \mathrm{a}_{\mathrm{ijr}}}{1}, \frac{\sum_{\mathrm{r}=1}^{1} \mathrm{~b}_{\mathrm{ijr}}}{1}, \frac{\sum_{\mathrm{r}=1}^{1} \mathrm{c}_{\mathrm{ijr}}}{1}\right) \equiv\left(\mathrm{a}_{\mathrm{ij}}, \mathrm{b}_{\mathrm{ij}}, \mathrm{c}_{\mathrm{ij}}\right), \\
\mathrm{W}_{\mathrm{ij}} \equiv\left(\frac{\sum_{\mathrm{r}=1}^{1} \mathrm{x}_{\mathrm{ijr}}}{1}, \frac{\sum_{\mathrm{r}=1}^{1} \mathrm{y}_{\mathrm{ijr}}}{1}, \frac{\sum_{\mathrm{r}=1}^{1} \mathrm{z}_{\mathrm{ijr}}}{1}\right) \equiv\left(\mathrm{x}_{\mathrm{ij}}, \mathrm{y}_{\mathrm{ij}}, \mathrm{z}_{\mathrm{ij}}\right) .
\end{gathered}
$$

Similarly, the weight $\mathrm{W}_{\mathrm{i}}$ for each enabler $\mathrm{i}$ is calculated using Equation (3).

$$
\mathrm{W}_{\mathrm{i}} \equiv\left(\frac{\sum_{\mathrm{r}=1}^{1} \mathrm{x}_{\mathrm{ir}}}{1}, \frac{\sum_{\mathrm{r}=1}^{\mathrm{l}} \mathrm{y}_{\mathrm{ir}}}{1}, \frac{\sum_{\mathrm{r}=1}^{\mathrm{l}} \mathrm{z}_{\mathrm{ir}}}{1}\right) \equiv\left(\mathrm{x}_{\mathrm{i}}, \mathrm{y}_{\mathrm{i}}, \mathrm{z}_{\mathrm{i}}\right) .
$$

In Equations (1)-(3), $\mathrm{i}=1$ to $\mathrm{m}$, and $\mathrm{j}=1$ to $\mathrm{n}$.

Step 4: Determination of overall agility fuzzy index at the enabler level. The overall fuzzy agility index consolidates the fuzzy ratings and weights of all enablers and attributes that effect the supply 
chain agility. The fuzzy agility index represents the overall organizational agility that is used to determine the organization's agility level. The membership function of the fuzzy agility index is calculated using the fuzzy weighted average operation [59]. Equation (4) is used to calculate the overall fuzzy agility index $\left(\mathrm{AI}_{\mathrm{i}}\right)$ for each enabler $\mathrm{i}[50,72]$.

$$
\mathrm{AI}_{\mathrm{i}} \equiv\left(\frac{\sum_{\mathrm{j}=1}^{\mathrm{n}}\left(\mathrm{x}_{\mathrm{ij}} * \mathrm{a}_{\mathrm{ij}}\right)}{\sum_{\mathrm{j}=1}^{\mathrm{n}} \mathrm{x}_{\mathrm{ij}}}, \frac{\sum_{\mathrm{j}=1}^{\mathrm{n}}\left(\mathrm{y}_{\mathrm{ij}} * \mathrm{~b}_{\mathrm{ij}}\right)}{\sum_{\mathrm{j}=1}^{\mathrm{n}} \mathrm{y}_{\mathrm{ij}}}, \frac{\sum_{\mathrm{j}=1}^{\mathrm{n}}\left(\mathrm{z}_{\mathrm{ij}} * \mathrm{c}_{\mathrm{ij}}\right)}{\sum_{\mathrm{j}=1}^{\mathrm{n}} \mathrm{z}_{\mathrm{ij}}}\right) \equiv\left(\mathrm{d}_{\mathrm{i}}, \mathrm{e}_{\mathrm{i}}, \mathrm{f}_{\mathrm{i}}\right) .
$$

Step 5: Determination of the supply chain agility index. Using agility fuzzy indices of enablers (Step 4 and Table 3), the supply chain agility index (SCAI) is identified using Equation (5):

$$
\text { Supply chain agility fuzzy index }(\mathrm{SCAI}) \equiv\left(\frac{\sum_{\mathrm{i} 1}^{\mathrm{m}}\left(\mathrm{x}_{\mathrm{i}} * \mathrm{~d}_{\mathrm{i}}\right)}{\sum_{\mathrm{i}=1}^{\mathrm{m}} \mathrm{x}_{\mathrm{i}}}, \frac{\sum_{\mathrm{i}=1}^{\mathrm{m}}\left(\mathrm{y}_{\mathrm{i}} * \mathrm{e}_{\mathrm{i}}\right)}{\sum_{\mathrm{i}=1}^{\mathrm{m}} \mathrm{y}_{\mathrm{i}}}, \frac{\sum_{\mathrm{i}=1}^{\mathrm{m}}\left(\mathrm{z}_{\mathrm{i}} * \mathrm{f}_{\mathrm{i}}\right)}{\sum_{\mathrm{i}=1}^{\mathrm{m}} \mathrm{z}_{\mathrm{i}}}\right) \equiv(\mathrm{g}, \mathrm{h}, \mathrm{k}) \text {. }
$$

Step 6: Matching the SCAI with the linguistic terms to identify the agility level. Once the agility index is obtained (see Equation (5)) to identify the supply chain agility level, the agility index can be matched with the appropriate linguistic terms. Several different methods were proposed to match membership functions with linguistic terms, including Euclidean distance [61] successive approximation [73] and piecewise decomposition [73,74]. The Euclidean distance D between the SCAI and SCAL can be calculated using Equation (6) [51,75], where $t=1$ to 5 are five agility level linguistic terms (or members), and $\left(o_{t}, q_{t}, s_{t}\right)$ is the corresponding fuzzy number for the given $t$.

$$
\begin{gathered}
\mathrm{D}\left(\mathrm{SCAI}, \mathrm{SCAL}_{\mathrm{t}}\right)=\left\{\sum_{\mathrm{u} \in \mathrm{p}}\left[\mathrm{f}_{\mathrm{SCAI}}(\mathrm{u})-\mathrm{f}_{\mathrm{AL}}(\mathrm{u})\right]^{2}\right\}^{\frac{1}{2}} \\
\equiv \mathrm{D}\left[(\mathrm{g}, \mathrm{h}, \mathrm{k}),\left(\mathrm{o}_{\mathrm{t}}, \mathrm{q}_{\mathrm{t}}, \mathrm{s}_{\mathrm{t}}\right)\right]=\left\{\left(\mathrm{g}-\mathrm{o}_{\mathrm{t}}\right)^{2}+\left(\mathrm{h}-\mathrm{q}_{\mathrm{t}}\right)^{2}+\left(\mathrm{k}-\mathrm{s}_{\mathrm{t}}\right)^{2}\right\}^{1 / 2} .
\end{gathered}
$$

The Euclidean distances (for $t=1$ to 5 ) are tabulated in the following matrix.

$$
\begin{aligned}
& \mathrm{D}\left(\mathrm{SCAI}, \mathrm{SCAL}_{\mathrm{t}}\right)=\operatorname{Minimum} \text { of }\left\{\begin{array}{ccc}
\text { agility level } \downarrow & \mathbf{t} \downarrow & \mathbf{D} \downarrow \\
\text { extreamly agile } & 1 & 0.300 \\
\text { very agile } & 2 & 0.043 \\
\text { agile } & 3 & 0.307 \\
\text { fairly agile } & 4 & 0.653 \\
\text { slowly agile } & 5 & 0.913
\end{array}\right\}= \\
& {[\mathrm{t}=2 \text {, i.e., very agile agility level }] .}
\end{aligned}
$$

Step 7: Identify barriers to improve the supply chain agility. After defining the supply chain agility level of the case organization, a fuzzy performance index (FPI) is calculated to identify the barriers to improve the agility level. The FPI is an index that combines the performance rating and importance weight of each agile supply chain-enabler-attribute and influences the sustainability level. The contribution degree for a factor of agile supply decreases with decreasing FPI. Therefore, the FPI score of a factor is used to define the main barriers of the agile supply chain. Equation (7) can be used to obtain the FPI $[66,70,71]$ :

$$
\mathrm{FPI}_{\mathrm{ij}}=\left[1-\mathrm{W}_{\mathrm{ij}}\right] * \mathrm{R}_{\mathrm{ij}} \equiv\left(\mathrm{A}_{\mathrm{ij}}, \mathrm{B}_{\mathrm{ij}}, \mathrm{C}_{\mathrm{ij}}\right)=\left(\left[1-\mathrm{x}_{\mathrm{ij}}\right] * \mathrm{a}_{\mathrm{ij}},\left[1-\mathrm{y}_{\mathrm{ij}}\right] * \mathrm{~b}_{\mathrm{ij}},\left[1-\mathrm{z}_{\mathrm{ij}}\right] * \mathrm{c}_{\mathrm{ij}}\right) .
$$


Table 2. Capabilities, enablers, and attributes for evaluating agility in supply chains.

\begin{tabular}{|c|c|c|c|c|c|c|}
\hline \multirow{2}{*}{$C^{\#}$} & \multirow{2}{*}{$\begin{array}{c}E_{i} \\
i\end{array}$} & & \multicolumn{2}{|r|}{$A_{i, j}$} & \multicolumn{2}{|r|}{$\mathbf{A}_{\mathrm{i}, \mathrm{j}}$} \\
\hline & & & $\mathbf{j}$ & Attribute & $\mathbf{j}$ & Attribute \\
\hline \multirow{10}{*}{ Responsiveness } & \multirow{10}{*}{1} & \multirow{10}{*}{$\begin{array}{l}\text { Organization } \\
\text { Management }\end{array}$} & 1 & Material planning $[17,37,67]$ & 11 & $\begin{array}{l}\text { Integration of IT in product development } \\
\qquad[33,38,67]\end{array}$ \\
\hline & & & 2 & Integrated logistic networks $[17,37,67,76]$ & 12 & $\begin{array}{c}\text { Integration of IT in outsourcing efficiency } \\
\qquad[33,38,67]\end{array}$ \\
\hline & & & 3 & Virtual logistics $[17,37,67,76]$ & 13 & Integration of IT in reverse logistics $[33,38,67,76]$ \\
\hline & & & 4 & Innovative organization $[17,37,67,76]$ & 14 & Fast team building $[33,38,67]$ \\
\hline & & & 5 & Organizational structure $[33,37,67]$ & 15 & Interchangeability of personnel $[33,38,67]$ \\
\hline & & & 6 & Distribution networks $[9,17,38,67]$ & 16 & Team decision making $[33,38,67]$ \\
\hline & & & 7 & Transportation facilities $[17,33,38,67,76]$ & 17 & Manufacturing capabilities $[9,38,67,76]$ \\
\hline & & & 8 & Warehousing and procurement $[9,17,38,67]$ & 18 & Process and technological capabilities $[33,38,67,76]$ \\
\hline & & & 9 & $\begin{array}{l}\text { Order Processing and fulfilment strategy } \\
\qquad[17,33,38,67,76]\end{array}$ & 19 & Cooperating with companies $[17,38,67]$ \\
\hline & & & 10 & $\begin{array}{l}\text { Integration of IT in supply chain management } \\
\qquad[17,33,38,67,76]\end{array}$ & 20 & Demand of supply planning $[33,38,67,76]$ \\
\hline \multirow{9}{*}{ Competency } & \multirow{9}{*}{2} & \multirow{9}{*}{$\begin{array}{c}\text { Strategic } \\
\text { Management }\end{array}$} & 1 & Innovative infrastructure $[9,38,67]$ & 18 & Corporate and business strategies $[15,38,67]$ \\
\hline & & & 2 & Functional and departmental integration $[28,57]$ & 19 & Streamlining of processes $[38,67]$ \\
\hline & & & 3 & Participative management style $[38,67]$ & 20 & Excellent communication $[17,38,67]$ \\
\hline & & & 4 & Synchronized material movement $[9,17,38,67]$ & 21 & Proper scheduling of activities $[34,38,67]$ \\
\hline & & & 5 & Effective training $[9,17,38,67]$ & 22 & Easy maintainability and serviceability $[38,67]$ \\
\hline & & & 6 & Well-defined procedures and forms $[9,17,38,67]$ & 23 & Removing organizational walls [67] \\
\hline & & & 7 & Flexible software for agility $[9,17,38,67]$ & 24 & Pull production system $[38,67,76]$ \\
\hline & & & 8 & Data management framework $[38,49,76]$ & 25 & Parallel operations $[17,38,67]$ \\
\hline & & & 9 & Product design at least price $[9,38]$ & 26 & Effective utilization of time $[38,67]$ \\
\hline
\end{tabular}


Table 2. Cont

\begin{tabular}{|c|c|c|c|c|c|c|}
\hline \multirow{2}{*}{$C^{\#}$} & \multirow{2}{*}{$\begin{array}{c}E_{i} \\
i\end{array}$} & & \multicolumn{2}{|r|}{$\mathbf{A}_{\mathrm{i}, \mathrm{j}}$} & \multicolumn{2}{|r|}{$\mathbf{A}_{\mathbf{i}, \mathbf{j}}$} \\
\hline & & & $\mathbf{j}$ & Attribute & $\mathbf{j}$ & Attribute \\
\hline & & & 10 & $\begin{array}{l}\text { Suitable design for supply chain paradigm } \\
\qquad[37,49,77]\end{array}$ & 27 & Strategic SCM network $[38,67]$ \\
\hline & & & 11 & Rapid decision making $[38,67]$ & 28 & Quality ensured at every stage $[17,33,38,67]$ \\
\hline & & & 12 & Top management commitment $[37,49,76]$ & 29 & Zero-inventory system $[38,67,76]$ \\
\hline & & & 13 & Management goal $[39,67]$ & 30 & Time compression technologies $[17,38,67]$ \\
\hline & & & 14 & Frequent management employees meeting $[38,67]$ & 31 & Product development methods $[9,33,38,67]$ \\
\hline & & & 15 & Short range planning $[38,67]$ & 32 & Producing new product $[17,33,38,67]$ \\
\hline & & & 16 & Customer delight $[38,67]$ & 33 & Time schedule-based procurement policy $[38,67]$ \\
\hline & & & 17 & Transparent information sharing $[33,38,67]$ & 34 & Product/process/service design on quality $[38,67]$ \\
\hline \multirow{6}{*}{ Flexibility } & \multirow{6}{*}{3} & \multirow{6}{*}{$\begin{array}{c}\text { Strategic } \\
\text { Commitment }\end{array}$} & 1 & Numerous suppliers [33] & 7 & Negotiation $[33,38,67,76]$ \\
\hline & & & 2 & Concurrent execution activities $[33,38,67,76]$ & 8 & Recognizing required agile capabilities $[6,57,73]$ \\
\hline & & & 3 & Interlinking departments $[33,38,67,76]$ & 9 & $\begin{array}{c}\text { Understanding characteristics of business } \\
\text { environment }[6,57,73]\end{array}$ \\
\hline & & & 4 & Networking with partners $[9,33,38,67,76]$ & 10 & $\begin{array}{l}\text { Integration of core competencies with process } \\
\text { excellence [6] }\end{array}$ \\
\hline & & & 5 & Creating an agile supporting culture [77] & 11 & $\begin{array}{l}\text { Integration of intellectual property and data with } \\
\text { partners [28] }\end{array}$ \\
\hline & & & 6 & $\begin{array}{l}\text { Customers/suppliers trust and competence } \\
\qquad[33,38,67,76]\end{array}$ & 12 & $\begin{array}{l}\text { Integration of marketing information with } \\
\text { network associate }[33,77]\end{array}$ \\
\hline \multirow{4}{*}{ Quickness } & \multirow{4}{*}{4} & \multirow{4}{*}{$\begin{array}{l}\text { Information } \\
\text { Management }\end{array}$} & 1 & $\begin{array}{l}\text { Capturing demand information immediately } \\
\qquad[6,28,77]\end{array}$ & 6 & World Wide Web $[38,67]$ \\
\hline & & & 2 & Keeping information on file $[6,28]$ & 7 & Incorporating RFID technology $[33,38,67]$ \\
\hline & & & 3 & Efficient funds transfer $[9,38,67]$ & 8 & Response time to customer $[33,38,67]$ \\
\hline & & & 4 & Partners' feedback [77] & 9 & Multimedia utilization $[38,67]$ \\
\hline
\end{tabular}


Table 2. Cont

\begin{tabular}{|c|c|c|c|c|c|c|}
\hline \multirow{2}{*}{$C^{\#}$} & \multirow{2}{*}{$\begin{array}{c}E_{i} \\
i\end{array}$} & & \multicolumn{2}{|r|}{$A_{i, j}$} & \multicolumn{2}{|r|}{$\mathbf{A}_{\mathbf{i}, \mathbf{j}}$} \\
\hline & & & $\mathbf{j}$ & Attribute & $\mathbf{j}$ & Attribute \\
\hline & & & 5 & Information accessibility dimensions $[6,77]$ & 10 & Early disturbances detection $[6,77]$ \\
\hline & \multirow{4}{*}{5} & \multirow{4}{*}{$\begin{array}{l}\text { Customer } \\
\text { Sensitivity }\end{array}$} & 1 & Accurate customer-based measures $[38,67]$ & 5 & Product release acceleration $[6,77]$ \\
\hline & & & 2 & Customer driven manufacturing $[38,67]$ & 6 & Opportunities to increase customer value $[38,67]$ \\
\hline & & & 3 & Market trend analysis $[33,38,67]$ & 7 & Effective forecasting method $[33,38,67]$ \\
\hline & & & 4 & Similar products structure $[6,77]$ & 8 & Part universalization degree [6] \\
\hline & \multirow{5}{*}{6} & \multirow{5}{*}{$\begin{array}{l}\text { Human } \\
\text { Competence }\end{array}$} & 1 & $\begin{array}{l}\text { Employees ability in supporting top management } \\
\qquad[6,28,77]\end{array}$ & 6 & Meeting customer requirements $[28,77]$ \\
\hline & & & 2 & $\begin{array}{c}\text { Employees ability in making appropriate response } \\
\text { to market changes }[6,77]\end{array}$ & 7 & Evaluating supply chain operations $[28,77]$ \\
\hline & & & 3 & $\begin{array}{l}\text { Employees ability in participation in strategy } \\
\text { formulation and planning }[6,77]\end{array}$ & 8 & $\begin{array}{l}\text { Continually updating and revising strategies } \\
\qquad[28,77]\end{array}$ \\
\hline & & & 4 & $\begin{array}{l}\text { Employees ability in working proactively to } \\
\text { identify opportunities }[6,77]\end{array}$ & 9 & Minimizing resistance to change $[28,77]$ \\
\hline & & & 5 & Managing supply chain resources $[6,77]$ & & \\
\hline
\end{tabular}

\# Abbreviations: C: capabilities, i: enabler number, $\mathrm{j}$ : attribute number, $\mathrm{E}_{\mathrm{i}}$ : enablers, $\mathrm{A}_{\mathrm{ij}}$ : attributes of agile supply chain. 
Table 3. Performance rating and weighting scale with corresponding fuzzy numbers.

\begin{tabular}{cccc}
\hline \multicolumn{2}{c}{ Performance Ratings (R) } & \multicolumn{2}{c}{ Importance Weights (W) } \\
\hline Symbol: Linguistic Variable & Fuzzy Number & Symbol: Linguistic Variable & Fuzzy Number \\
\hline W: Worst & $(0.00,0.05,0.15)$ & VL: Very Low & $(0.00,0.05,0.15)$ \\
VP: Very Poor & $(0.10,0.20,0.30)$ & L: Low & $(0.10,0.20,0.30)$ \\
P: Poor & $(0.20,0.35,0.50)$ & FL: Fairly Low & $(0.20,0.35,0.50)$ \\
F: Fair & $(0.30,0.50,0.70)$ & M: Average & $(0.30,0.50,0.70)$ \\
G: Good & $(0.50,0.65,0.80)$ & FH: Fairly High & $(0.50,0.65,0.80)$ \\
VG: Very Good & $(0.70,0.80,0.90)$ & H: High & $(0.70,0.80,0.90)$ \\
E: Excellent & $(0.85,0.95,1.00)$ & VH: Very High & $(0.85,0.95,1.00)$ \\
\hline
\end{tabular}

In Equation (7), $\mathrm{FPI}_{\mathrm{ij}} \approx\left(\mathrm{A}_{\mathrm{ij}}, \mathrm{B}_{\mathrm{ij}}, \mathrm{C}_{\mathrm{ij}}\right)$ is the fuzzy performance importance index, $\mathrm{R}_{\mathrm{ij}} \approx\left(\mathrm{a}_{\mathrm{ij}}, \mathrm{b}_{\mathrm{ij}}, \mathrm{c}_{\mathrm{ij}}\right)$ is the fuzzy ratings, and $\mathrm{W}_{\mathrm{ij}} \approx\left(\mathrm{x}_{\mathrm{ij}}, \mathrm{y}_{\mathrm{ij}}, \mathrm{z}_{\mathrm{ij}}\right)$ is the fuzzy weights for each attribute $\mathrm{j}$ for a given enabler i. Because fuzzy numbers do not always result in a fully ordered set of real numbers, FPIs should be ranked. Several methods have been devised to rank fuzzy numbers [75]. Here, the left-and-right fuzzy-ranking method was used to rank fuzzy numbers [76-80]. This method considers the absolute location of each fuzzy number and preserves the ranking order. The only disadvantage of the left-and-right fuzzy-ranking method is that as different fuzzy maximizing and minimizing sets are used, the ranking score will be different [64]. In this presented assessment framework, the maximizing and minimizing fuzzy sets are defined as

$$
\begin{gathered}
\mathrm{U}_{\max (\mathrm{x})}=\left\{\begin{array}{cc}
x, & 0 \leq x \leq 1, \\
0, & \text { otherwise }
\end{array}\right\}, \\
\mathrm{U}_{\min (\mathrm{x})}=\left\{\begin{array}{ll}
1-x, & 0 \leq x \leq 1, \\
0, & \text { otherwise }
\end{array}\right\} .
\end{gathered}
$$

Due to an FPI with a triangular-fuzzy number, the right and left FPI scores can be calculated using Equations (10) and (11), respectively [56], as follows (Equations (10) and (12)).

$$
\begin{aligned}
& \mathrm{U}_{\mathrm{R}}\left(\mathrm{FPI}_{\mathrm{ij}}\right)=\sup _{\mathrm{x}}\left[\mathrm{U}_{\mathrm{FPI}_{\mathrm{ij}}}(\mathrm{x}) \mathrm{U}_{\max (\mathrm{x})}\right]=\frac{\mathrm{C}_{\mathrm{ij}}}{1+\mathrm{C}_{\mathrm{ij}}-\mathrm{B}_{\mathrm{ij}}}, \\
& \mathrm{U}_{\mathrm{L}}\left(\mathrm{FPI}_{\mathrm{ij}}\right)=\sup _{\mathrm{x}}\left[\mathrm{U}_{\mathrm{FPI}_{\mathrm{ij}}}(\mathrm{x}) \mathrm{U}_{\min (\mathrm{x})}\right]=\frac{1-\mathrm{A}_{\mathrm{ij}}}{1+\mathrm{B}_{\mathrm{ij}}-\mathrm{A}_{\mathrm{ij}}},
\end{aligned}
$$

where $\sup _{\mathrm{x}}\left[\mathrm{U}_{\mathrm{FPI}_{\mathrm{ij}}}(\mathrm{x}) \mathrm{U}_{\max (\mathrm{x})}\right]$ is the ordinate of the intersecting point of $\mathrm{U}_{\max }$ and the right leg of $\mathrm{U}_{\mathrm{FPI}_{\mathrm{ij}}}$, and similarly, $\sup _{\mathrm{x}}\left[\mathrm{U}_{\mathrm{FPI}_{\mathrm{ij}}}(\mathrm{x}) \mathrm{U}_{\min (\mathrm{x})}\right]$ is the ordinate of the intersecting point of $\mathrm{U}_{\min }$ and the left leg of $\mathrm{U}_{\mathrm{FPI}_{\mathrm{ij}}}$. Finally, the total FPI score can be obtained by combining the left and right scores. The FPI is calculated using Equation (12).

$$
\mathrm{U}_{\mathrm{T}}\left(\mathrm{FPI}_{\mathrm{ij}}\right)=\frac{\mathrm{U}_{\mathrm{R}}\left(\mathrm{FPI}_{\mathrm{ij}}\right)+1-\mathrm{U}_{\mathrm{L}}\left(\mathrm{FPI}_{\mathrm{ij}}\right)}{2} .
$$

It is evident that complex mathematical equations are very difficult to solve by industrial experts. It is apparent that decision makers at the case organization need a user-friendly fuzzy DSS process accessible from the workplace to evaluate supply chain agility [34,81]. Microsoft and its accompanying VBA programming language offered the tools needed to create a functional, user-friendly DSS [69]. Due to the widespread availability of the Microsoft package, most manufacturing organizations could use this fuzzy DSS without having to purchase additional specialized software. Thus, a fuzzy DSS process to evaluate supply chain agility for a Saudi manufacturing organization is herewith proposed and adopted, which includes two steps, each of which are illustrated in the following subsection. 


\subsection{Fuzzy-DSS "Response" Interface}

First, the decision maker sends the "Response" file to supply chain agility experts. Multiple assessors, key experts, and top management in the organization examine challenges in the business supply chain environment and identify performance evaluation rating and importance. The step-by-step flow of the "Response" interface in the form of computer screenshots is presented in Figure 2.
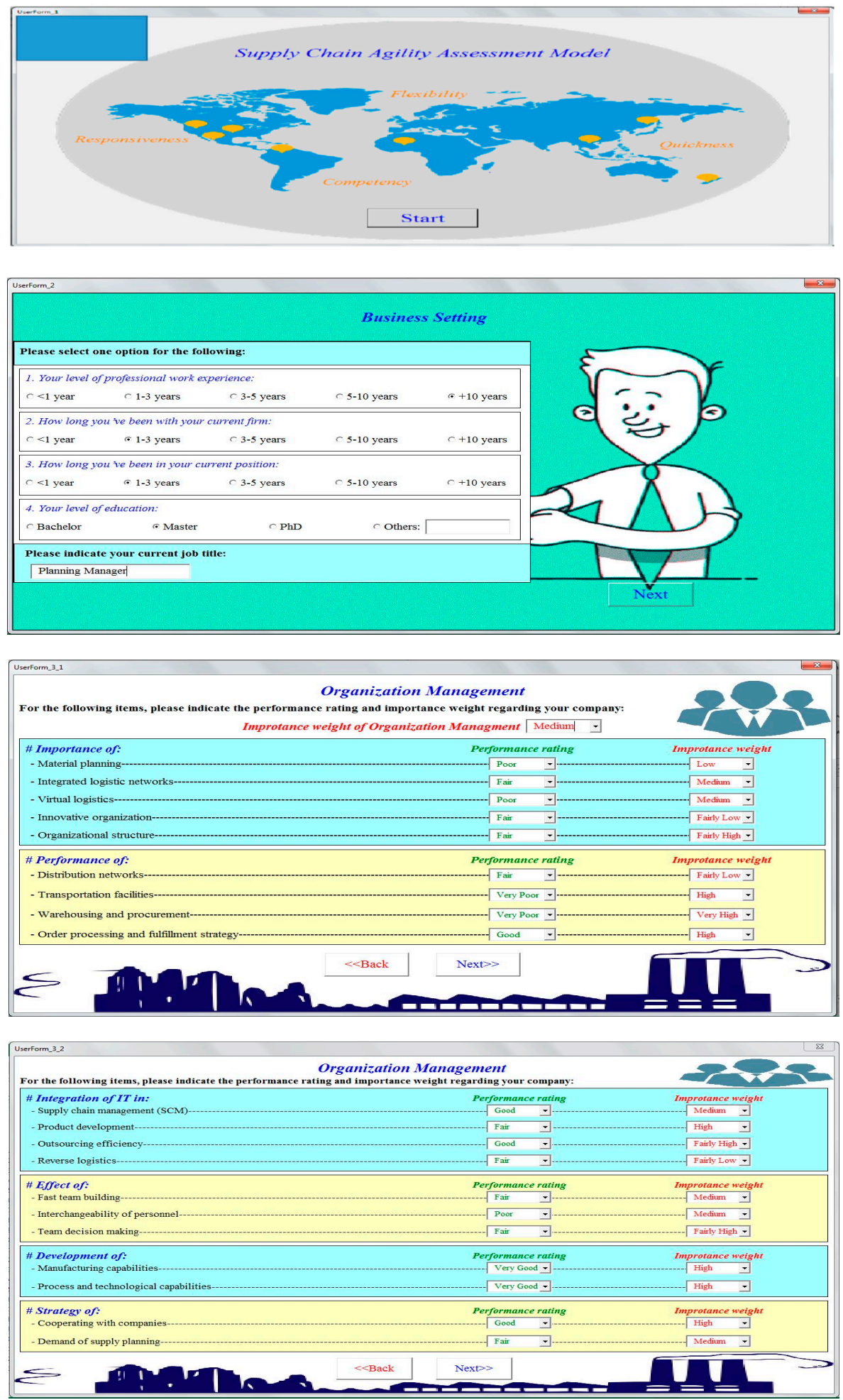

Figure 2. Cont. 

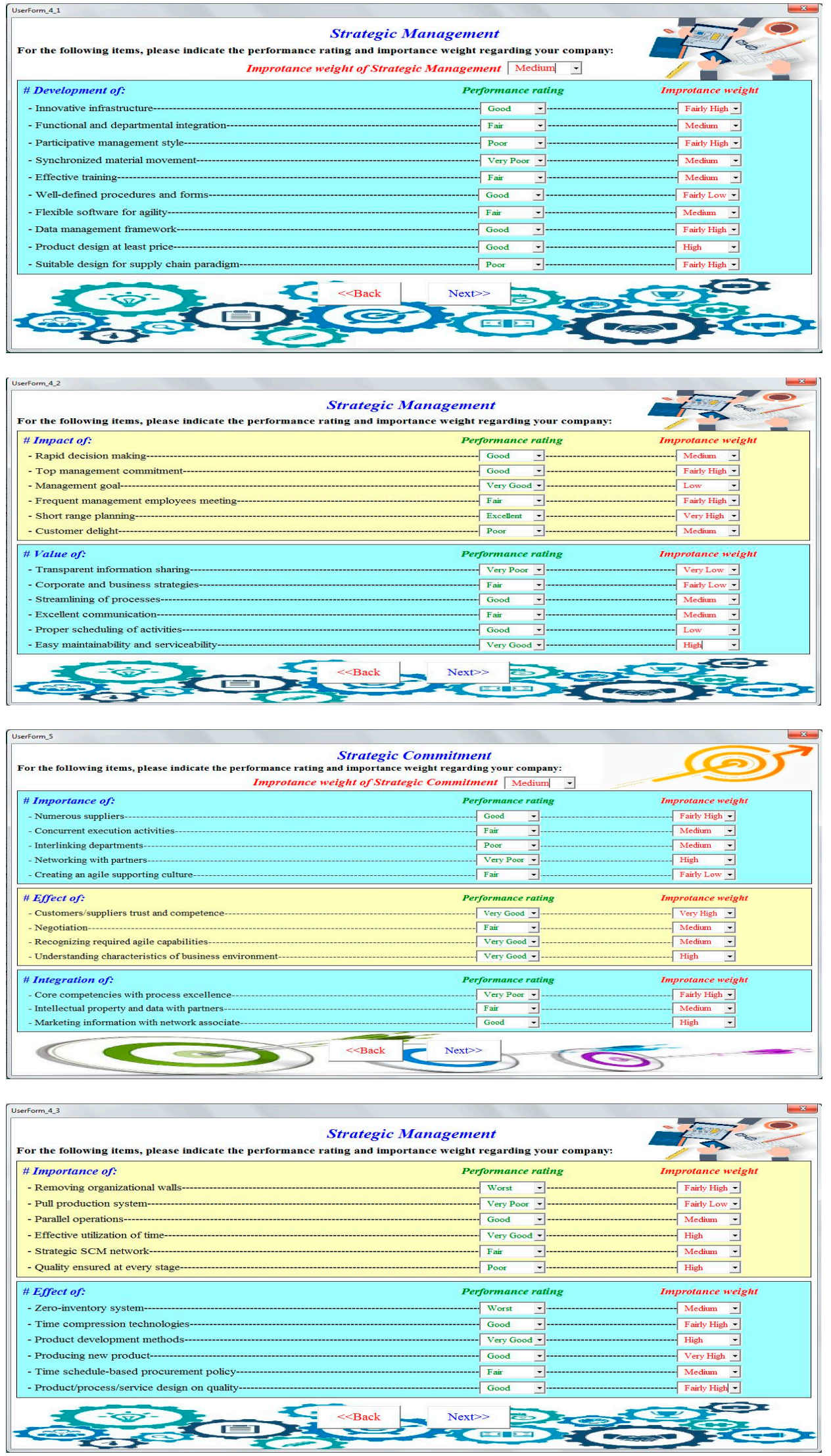

Figure 2. Cont. 

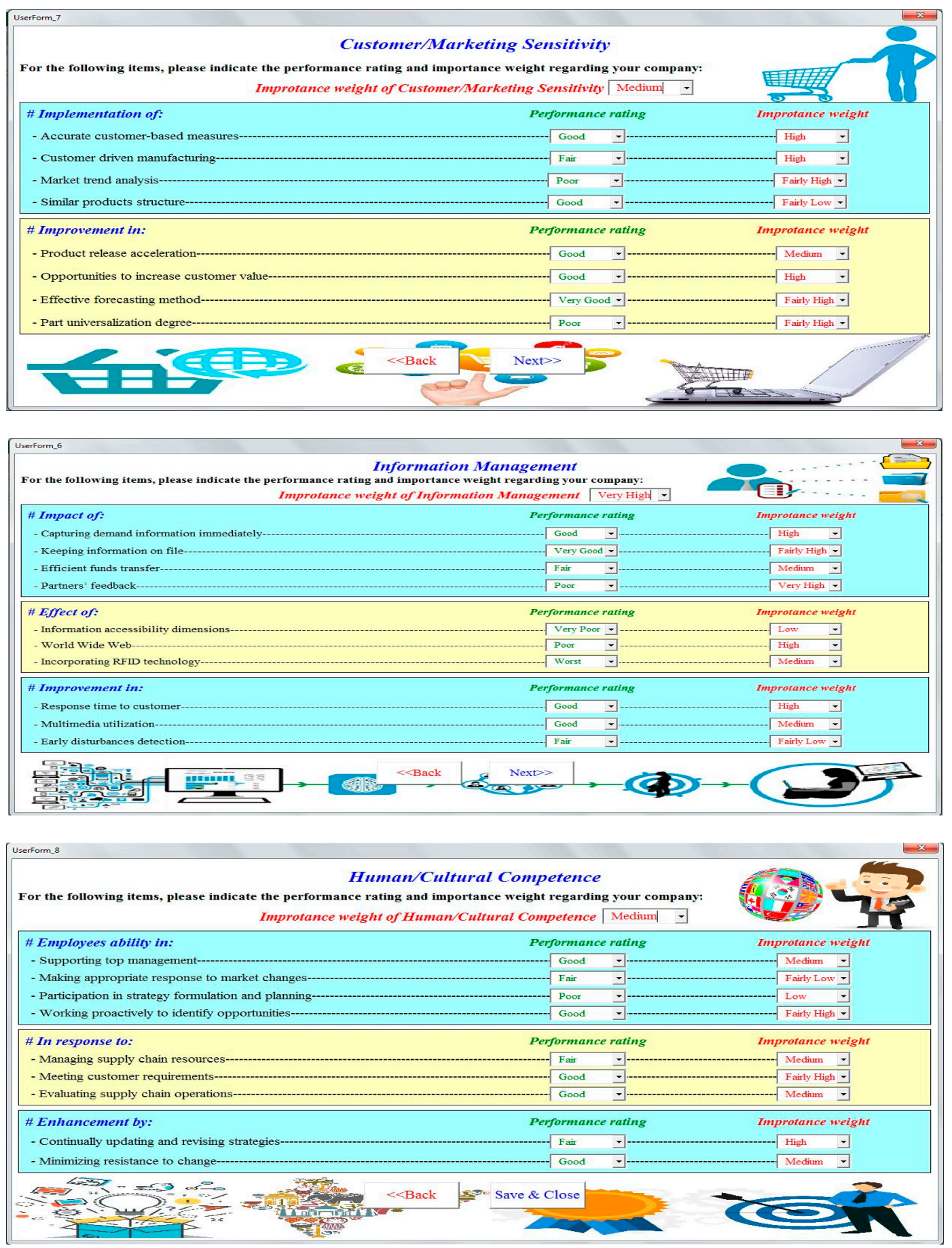

Figure 2. Screenshots of the "Response" interface.

\subsection{Fuzzy-DSS “Assessment" Interface}

When a decision maker starts the "Assessment" interface, they receive a password to log in. The user chooses to "Transfer Data" from the "Response" interface to the "Assessment" interface. Once the data have been transferred to the assessment interface, calculations using the various equations required to assess the supply chain agility, which are described in Section 4, are performed to estimate fuzzy numbers that are further used to approximate the linguistic terms to assess the agility level. The step-by-step flow of the "Assessment" interface in the form of computer screenshots is presented in Figure 3. 

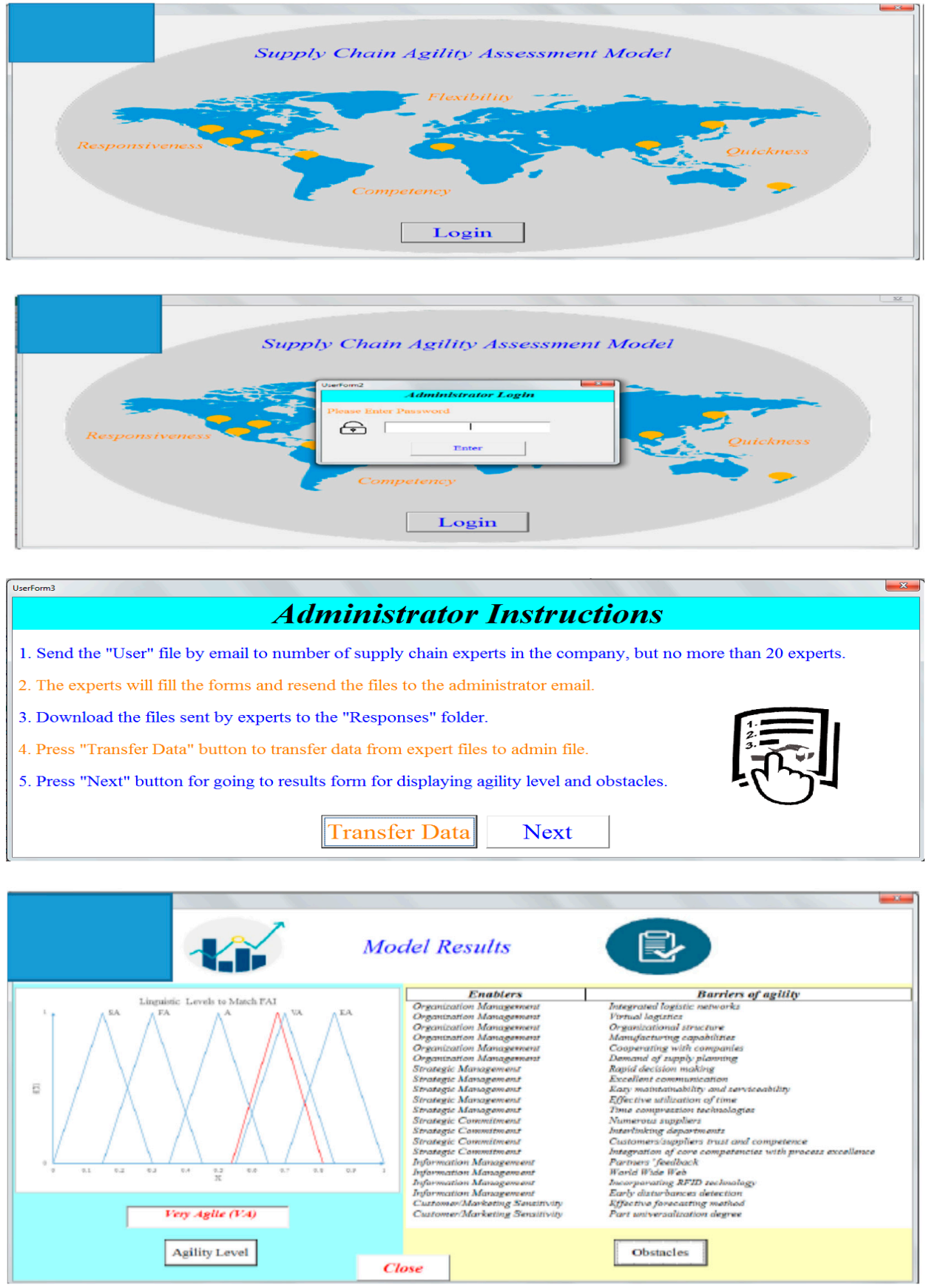

Figure 3. Screenshots of the "Assessment" Interface.

Thus, by applying fuzzy-DSS to the case organization, the proposed model highlights the agility level, enablers, and corresponding barriers. The proposed multi-criteria approach assists a manager in the decision making. Moreover, the approach helps to investigate enablers and barriers that pose obstacles to have an agile sustainable and competitive environment in an ever-changing dynamic demand market in context of a Saudi manufacturing organization.

\subsection{Validation of Fuzzy-DSS}

We created the validation plan as well as identified users in the organization and defined to them the process requirements. Furthermore, we asked to follow the flow of information as well as to generate the final report highlighting barriers to be considered in improving the supply chain sustainable agility. The reports were discussed with top management and we took their valuable 
suggestions into account. Top management placed more emphasis on strategic issues, especially rapid decision making and effective utilization of time. They also focused on cost, process management, highlighted market, and customer economics. Finally, they also mentioned the impact of various management practices on supply chain agility to foster sustainability. Thus, validation of fuzzy-DSS is done to check whether the software tool is up to the desired mark.

\section{Discussion and Results}

Supply chain agility has become an important avenue for any organization to survive and compete in a changing and dynamic global market. Within the organization, one should understand and estimate where the agility of their supply chain stands. In this paper, a fuzzy logic assessment approach supported with a visual basic decision support system was presented. For the purpose of validating the conceptual model an assessment approach was applied to do the assessment of the supply chain for a manufacturing organization located in Saudi Arabia. The results of the fuzzy assessment in the case organization provides evidence that the DSS model has a smooth application, indicating its practical validity and compatibility. It was estimated that the case manufacturing organization supply chain is "VA: very agile" with a fuzzy agility index of $0.538,0.678$, and 0.815 , although this value is below the "EA: extremely agile" rating $(0.700,0.850,1.000)$. There were 21 barriers out of the total 93 attributes within the supply chain that impacted the agility level. These barriers (see Table 4) were identified by a computation of ranking scores of agile supply chain attributes to be considered in improving the supply chain performance. Within selected barriers, the case organization should focus on strategies to achieve an easy maintainability and serviceability and an integration of core competencies with process excellence, on a priority basis, and the least preference should be given to demand supply planning and supply chain partners' feedback. Because of the time constraint, the supply chain assessment was conducted in a manufacturing organization. However, the results of this research can reasonably represent the situation prevailing in companies implementing world class strategies.

Table 4. The supply chain agility enablers, barriers to foster sustainability, and corresponding ranking score.

\begin{tabular}{ccc}
\hline Enablers. & Barriers & Ranking-Score \\
\hline & Logistic networks & 0.2404 \\
Organization Management & Virtual logistics & 0.2463 \\
& Organizational structure & 0.2353 \\
& Manufacturing capabilities & 0.2339 \\
& Cooperating with companies & 0.2404 \\
Strategic Management & Demand of supply planning & 0.2254 \\
\hline & Rapid decision making & 0.2382 \\
& Excellent communication & 0.2363 \\
& Easy maintainability and serviceability & 0.2481 \\
& Effective utilization of time & 0.2415 \\
Information Management & Time compression technologies & 0.2351 \\
& Numerous suppliers & 0.2438 \\
& Interlinking departments & 0.2382 \\
& Customers/suppliers trust and competence & 0.2339 \\
& Integration of core competencies with process excellence & 0.2481 \\
\hline \multirow{2}{*}{ Customer/Marketing Sensitivity } & Partners' feedback & 0.2137 \\
& World Wide Web & 0.2421 \\
\hline \multirow{2}{*}{$*$} & Incorporating RFID technology & 0.2371 \\
& Early disturbances detection & 0.2339 \\
\hline
\end{tabular}




\section{Conclusions and Future Research}

This paper is to consider and evaluate the supply chain behavior within the context of Saudi enterprises. The paper explored a Saudi dairy manufacturing corporation through a conducted case study. A multidisciplinary analysis of prior agility studies has been performed to clarify supply chain agility, considering the complex and multifaceted aspect of supply chain management. The emphasis was on sustainable supply chain agility multiple dimensions, such as organizational, strategic, commitment, informative, customer sensitivity, and human competence.

This paper focuses on Saudi manufacturing organizations seeking ways to improve their supply chain agility. Based on the literature review of multi-criteria assessment approaches, supply chain agility to foster sustainability for a manufacturing organization was preferred.

This paper identified six agility enablers and ninety-three agility attributes for the supply chain. The adopted approach takes into consideration opinions of experts and practitioners to understand relationships among different enablers and attributes, since it is not practically feasible to simultaneously focus on all enablers and attributes. Furthermore, it is evident that complex mathematical equations are very difficult to solve by industrial experts. Hence, we proposed a user-friendly and accessible-from-the-workplace fuzzy DSS process to evaluate supply chain agility for Saudi manufacturing organization.

This study paves the way for future research to conduct a number of local case studies for various organizations across the manufacturing and service sectors in Saudi Arabia. Moreover, more research is required to analyze the mediating factors affecting relationships between critical barriers. Such research would further aid manufacturing organizations to take control of the factors enabling or hindering the desired agility and sustainability. The proposed fuzzy DSS logic approach can be further enhanced by utilizing Internet of things (IoT) and machine learning to strengthen communications between the decision makers and various components of supply chains to expand the data sources. This study demonstrates the way for future research to validate the relationships between critical barriers of sustainable manufacturing in the context of developing countries.

Author Contributions: Conceptualization, A.U.R. and A.A.-Z.; methodology, A.U.R. and A.A.-Z.; software, A.U.R. and A.A.-Z.; validation, A.U.R., M.A, and U.U.; formal analysis, A.U.R. and M.A.; investigation, A.U.R and A.A.-Z.; resources, U.U. and Y.S.U.; data curation, A.U.R., Y.S.U., and U.U.; writing-original draft preparation, A.U.R.; writing-review and editing, U.U. and M.A.; supervision, A.U.R.; funding acquisition, A.U.R. and U.U. All authors have read and agree to the published version of the manuscript.

Funding: This research was funded by the Deanship of Scientific Research at King Saud University, grant number RG-1439-005.

Acknowledgments: The authors extend their appreciation to the Deanship of Scientific Research at King Saud University for funding this research through research group number RG-1439-005.

Conflicts of Interest: The authors declare no conflict of interest.

\section{References}

1. Gligor, D.M.; Esmark, C.L.; Holcomb, M.C. Performance outcomes of supply chain agility: When should you be agile? J. Oper. Manag. 2015, 34, 71-82. [CrossRef]

2. Poh, K.L.; Liang, Y. Multiple-Criteria Decision Support for a Sustainable Supply Chain: Applications to the Fashion Industry. Informatics 2017, 4, 36. [CrossRef]

3. Salam, M.A.; Ali, M.; Seny Kan, K.A. Analyzing Supply Chain Uncertainty to Deliver Sustainable Operational Performance: Symmetrical and Asymmetrical Modeling Approaches. Sustainability 2017, 9, 2217. [CrossRef]

4. Gunasekaran, A.; Patel, C.; Tirtiroglu, E. Performance measures and metrics in a supply chain environment. Int. J. Oper. Prod. Manag. 2001, 21, 71-87. [CrossRef]

5. Imrie, R.; Morris, J. A review of recent changes in buyer-supplier relations. Omega 1992, 20, 641-652. [CrossRef]

6. Zhang, Z.; Sharifi, H. A methodology for achieving agility in manufacturing organisations. Int. J. Oper. Prod. Manag. 2000, 20, 496-513. [CrossRef] 
7. Ahmed, M.U.; Pagell, M.; Kristal, M.M.; Gattiker, T.F. Micro-Foundations of Supply Chain Integration: An Activity-Based Analysis. Logistics 2019, 3, 12. [CrossRef]

8. Heizer, J.H.; Render, B. Operations Management; Pearson Education: London, UK, 2011; ISBN 978-0-13-511143-7.

9. Yusuf, Y.Y.; Gunasekaran, A.; Musa, A.; Dauda, M.; El-Berishy, N.M.; Cang, S. A relational study of supply chain agility, competitiveness and business performance in the oil and gas industry. Int. J. Prod. Econ. 2014, 147, 531-543. [CrossRef]

10. Wang, C.-N.; Tsai, H.-T.; Ho, T.-P.; Nguyen, V.-T.; Huang, Y.-F. Multi-Criteria Decision Making (MCDM) Model for Supplier Evaluation and Selection for Oil Production Projects in Vietnam. Processes 2020, 8, 134. [CrossRef]

11. Li, H.; Zhang, Z.; Zhao, Z.-Z. Data-Mining for Processes in Chemistry, Materials, and Engineering. Processes 2019, 7, 151. [CrossRef]

12. Vinodh, S.; Devadasan, S.R.; Vimal, K.E.K.; Kumar, D. Design of agile supply chain assessment model and its case study in an Indian automotive components manufacturing organization. J. Manuf. Syst. 2013, 32, 620-631. [CrossRef]

13. Christopher, M. The Agile Supply Chain: Competing in Volatile Markets. Ind. Mark. Manag. 2000, $29,37-44$. [CrossRef]

14. Gosling, J.; Purvis, L.; Naim, M.M. Supply chain flexibility as a determinant of supplier selection. Int. J. Prod. Econ. 2010, 128, 11-21. [CrossRef]

15. Tolone, W.J. Virtual situation rooms: Connecting people across enterprises for supply-chain agility. Comput. -Aided Des. 2000, 32, 109-117. [CrossRef]

16. Li, J.; Chen, C.-W.; Wu, C.-H.; Hung, H.-C.; Lin, C.-T. How do Partners Benefit from IT Use in Supply-Chain Management: An Empirical Study of Taiwan's Bicycle Industry. Sustainability 2020, 12, 2883. [CrossRef]

17. Aitken, J.; Christopher, M.; Towill, D. Understanding, Implementing and Exploiting Agility and Leanness. Int. J. Logist. Res. Appl. 2002, 5, 59-74. [CrossRef]

18. Kinney, M.R.; Wempe, W.F. Further Evidence on the Extent and Origins of JIT's Profitability Effects. Account. Rev. 2002, 77, 203-225. [CrossRef]

19. Felipe, C.M.; Roldán, J.L.; Leal-Rodríguez, A.L. Impact of Organizational Culture Values on Organizational Agility. Sustainability 2017, 9, 2354. [CrossRef]

20. Van Hoek, R.I.; Harrison, A.; Christopher, M. Measuring agile capabilities in the supply chain. Int. J. Oper. Prod. Manag. 2001, 21, 126-148. [CrossRef]

21. Swafford, P.M.; Ghosh, S.; Murthy, N. Achieving supply chain agility through IT integration and flexibility. Int. J. Prod. Econ. 2008, 116, 288-297. [CrossRef]

22. Jaradat, R.; Adams, F.; Abutabenjeh, S.; Keating, C. The Complementary Perspective of System of Systems in Collaboration, Integration, and Logistics: A Value-Chain Based Paradigm of Supply Chain Management. Systems 2017, 5, 50. [CrossRef]

23. Kisperska-Moron, D.; de Haan, J. Improving supply chain performance to satisfy final customers: "Leagile" experiences of a polish distributor. Int. J. Prod. Econ. 2011, 133, 127-134. [CrossRef]

24. Naim, M.M.; Gosling, J. On leanness, agility and leagile supply chains. Int. J. Prod. Econ. 2011, 131, 342-354. [CrossRef]

25. Prajogo, D.I.; Sohal, A.S. The relationship between organization strategy, total quality management (TQM), and organization performance-the mediating role of TQM. Eur. J. Oper. Res. 2006, 168, 35-50. [CrossRef]

26. Jain, V.; Benyoucef, L.; Deshmukh, S.G. A new approach for evaluating agility in supply chains using Fuzzy Association Rules Mining. Eng. Appl. Artif. Intell. 2008, 21, 367-385. [CrossRef]

27. Yadala, S.; Smith, J.D.; Young, D.; Crunkleton, D.W.; Cremaschi, S. Optimization of the Algal Biomass to Biodiesel Supply Chain: Case Studies of the State of Oklahoma and the United States. Processes 2020, 8, 476. [CrossRef]

28. Braunscheidel, M.J.; Suresh, N.C. The organizational antecedents of a firm's supply chain agility for risk mitigation and response. J. Oper. Manag. 2009, 27, 119-140. [CrossRef]

29. Doheny, M.; Nagali, V.; Weig, F. Agile operations for volatile times. Mckinsey Q. 2012, 3, 126-131.

30. Díaz-Curbelo, A.; Gento, Á.M.; Redondo, A.; Aqlan, F. A Fuzzy-Based Holistic Approach for Supply Chain Risk Assessment and Aggregation Considering Risk Interdependencies. Appl. Sci. 2019, 9, 5329. [CrossRef] 
31. Junaid, M.; Xue, Y.; Syed, M.W.; Li, J.Z.; Ziaullah, M. A Neutrosophic AHP and TOPSIS Framework for Supply Chain Risk Assessment in Automotive Industry of Pakistan. Sustainability 2020, 12, 154. [CrossRef]

32. Mishra, S.; Samantra, C.; Datta, S.; Mahapatra, S.S. Agility appraisement framework for integrated supply chain using generalised interval-valued fuzzy set. Int. J. Bus. Inf. Syst. 2014, 16, 89-118. [CrossRef]

33. Singh Patel, B.; Samuel, C.; Sharma, S.K. Evaluation of agility in supply chains: A case study of an Indian manufacturing organization. J. Manuf. Technol. Manag. 2017, 28, 212-231. [CrossRef]

34. Tse, Y.K.; Zhang, M.; Akhtar, P.; MacBryde, J. Embracing supply chain agility: An investigation in the electronics industry. Supply Chain Manag. Int. J. 2016, 21, 140-156. [CrossRef]

35. Christopher, M.; Lowson, R.; Peck, H. Creating agile supply chains in the fashion industry. Int. J. Retail Distrib. Manag. 2004, 32, 367-376. [CrossRef]

36. Gunasekaran, A.; Tirtiroglu, E.; Wolstencroft, V. An investigation into the application of agile manufacturing in an aerospace company. Technovation 2002, 22, 405-415. [CrossRef]

37. Vinodh, S.; Prasanna, M. Evaluation of agility in supply chains using multi-grade fuzzy approach. Int. J. Prod. Res. 2011, 49, 5263-5276. [CrossRef]

38. Vinodh, S.; Prakash, N.H.; Selvan, K.E. Evaluation of agility in supply chains using fuzzy association rules mining. Int. J. Prod. Res. 2011, 49, 6651-6661. [CrossRef]

39. Swafford, P.M.; Ghosh, S.; Murthy, N. The antecedents of supply chain agility of a firm: Scale development and model testing. J. Oper. Manag. 2006, 24, 170-188. [CrossRef]

40. Dwayne Whitten, G.; Green, K.W.; Zelbst, P.J. Triple-A supply chain performance. Int. J. Oper. Prod. Manag. 2012, 32, 28-48. [CrossRef]

41. Azevedo, S.G.; Govindan, K.; Carvalho, H.; Cruz-Machado, V. An integrated model to assess the leanness and agility of the automotive industry. Resour. Conserv. Recycl. 2012, 66, 85-94. [CrossRef]

42. Soni, G.; Kodali, R. Evaluating reliability and validity of lean, agile and leagile supply chain constructs in Indian manufacturing industry. Prod. Plan. Control 2012, 23, 864-884. [CrossRef]

43. Blome, C.; Schoenherr, T.; Rexhausen, D. Antecedents and enablers of supply chain agility and its effect on performance: A dynamic capabilities perspective. Int. J. Prod. Res. 2013, 51, 1295-1318. [CrossRef]

44. Garcia-Alcaraz, J.L.; Maldonado-Macias, A.A.; Alor-Hernandez, G.; Sanchez-Ramirez, C. The impact of information and communication technologies (ICT) on agility, operating, and economical performance of supply chain. Adv. Prod. Eng. Manag. 2017, 12, 29-40. [CrossRef]

45. Baramichai, M.; Zimmers, E.W.; Marangos, C.A. Agile supply chain transformation matrix: An integrated tool for creating an agile enterprise. Supply Chain Manag. Int. J. 2007, 12, 334-348. [CrossRef]

46. Saleeshya, P.G.; Thampi, K.S.; Raghuram, P. A combined AHP and ISM-based model to assess the agility of supply chain-A case study. Int. J. Integr. Supply Manag. 2012, 7, 167-191. [CrossRef]

47. Xu, N.-R.; Liu, J.-B. Research on Evaluation on Agility of Agile Supply Chain Network Based on Complex Network Theory. Available online: https://www.hindawi.com/journals/mpe/2015/707459/ (accessed on 25 April 2020).

48. Charles, A.; Lauras, M.; Van Wassenhove, L. A model to define and assess the agility of supply chains: Building on humanitarian experience. Int. J. Phys. Distrib. Logist. Manag. 2010, 40, 722-741. [CrossRef]

49. Raj, S.A.; Jayakrishna, K.; Vimal, K.E.K. Modelling the metrics of leagile supply chain and leagility evaluation. IJASM 2018, 11, 179. [CrossRef]

50. Oblak, L.; Kitek-Kuzman, M.; Grošelj, P. A fuzzy logic-based model for analysis and evaluation of services in a manufacturing company. J. Appl. Eng. Sci. 2017, 15, 258-271. [CrossRef]

51. Mehralian, G.; Zarenezhad, F.; Rajabzadeh Ghatari, A. Developing a model for an agile supply chain in pharmaceutical industry. Int. J. Pharm. Healthc. Mark. 2015, 9, 74-91. [CrossRef]

52. Matawale, C.R.; Datta, S.; Mahapatra, S.S. Agility appraisement and identification of agile barriers in a supply chain. Int. J. Serv. Oper. Manag. 2013, 16, 478-505. [CrossRef]

53. Samantra, C.; Datta, S.; Mishra, S.; Mahapatra, S.S. Agility appraisal for integrated supply chain using generalized trapezoidal fuzzy numbers set. Int. J. Adv. Manuf. Technol. 2013, 68, 1491-1503. [CrossRef]

54. Khalili-Damghani, K.; Tavana, M. A new fuzzy network data envelopment analysis model for measuring the performance of agility in supply chains. Int. J. Adv. Manuf. Technol. 2013, 69, 291-318. [CrossRef] 
55. Khalili-Damghani, K.; Sadi-Nezhad, S.; Hosseinzadeh-Lotfi, F. Imprecise DEA Models to Assess the Agility of Supply Chains. In Supply Chain Management Under Fuzziness: Recent Developments and Techniques; Kahraman, C., Öztayşi, B., Eds.; Studies in Fuzziness and Soft Computing; Springer: Berlin/Heidelberg, Germany, 2014; pp. 167-198. ISBN 978-3-642-53939-8.

56. Matawale, C.R.; Datta, S.; Mahapatra, S.S. Evaluation of leanness, agility and leagility for supply chain of automotive industries. Int. J. Agil. Syst. Manag. 2015, 8, 85-115. [CrossRef]

57. Wu, K.-J.; Tseng, M.-L.; Chiu, A.S.F.; Lim, M.K. Achieving competitive advantage through supply chain agility under uncertainty: A novel multi-criteria decision-making structure. Int. J. Prod. Econ. 2017, 190, 96-107. [CrossRef]

58. Liu, W.; Xu, H.; Zhao, X. Agile service oriented shipping companies in the container terminal. Transport 2009, 24, 143-153. [CrossRef]

59. Tsourveloudis, N.C.; Valavanis, K.P. On the Measurement of Enterprise Agility. J. Intell. Robot. Syst. 2002, 33, 329-342. [CrossRef]

60. Chen, Z. Agility indexes and application of production planning. Chin. J. Mech. Eng. 2006, 19, 352-355. [CrossRef]

61. Faisal, M.N.; Banwet, D.K.; Shankar, R. An approach to measure supply chain agility. Int. J. Ind. Syst. Eng. 2006, 2, 79-98. [CrossRef]

62. Kisperska-Moron, D.; Swierczek, A. The agile capabilities of Polish companies in the supply chain: An empirical study. Int. J. Prod. Econ. 2009, 118, 217-224. [CrossRef]

63. Sreenivasa, C.G.; Devadasan, S.R.; Murugesh, R. Enhancing total agility level through assessment and product mapping: A case study in the manufacturing of refrigeration air dryer. Int. J. Adv. Manuf. Technol. 2012, 60, 421-436. [CrossRef]

64. Vinodh, S.; Aravindraj, S. Agility evaluation using the IF-THEN approach. Int. J. Prod. Res. 2012, 50, 7100-7109. [CrossRef]

65. Elmoselhy, S.A. Hybrid Lean-Agile Manufacturing System Strategic Facet in Automotive Sector. SAE Int. J. Mater. Manuf. 2015, 8, 153-171. [CrossRef]

66. Balaji, M.; Velmurugan, V.; Subashree, C.; Balaji, M.; Velmurugan, V.; Subashree, C. TADS: An assessment methodology for agile supply chains. J. Appl. Res. Technol. 2015, 13, 504-509. [CrossRef]

67. Vinodh, S.; Sundararaj, G.; Devadasan, S.R.; Maharaja, R.; Rajanayagam, D.; Goyal, S.K. DESSAC: A decision support system for quantifying and analysing agility. Int. J. Prod. Res. 2008, 46, 6759-6780. [CrossRef]

68. Musaad,O.A.S.; Zhuo, Z.; Siyal, Z.A.; Shaikh, G.M.; Shah, S.A.A.; Solangi, Y.A.; Musaad, O.A.O. An Integrated Multi-Criteria Decision Support Framework for the Selection of Suppliers in Small and Medium Enterprises based on Green Innovation Ability. Processes 2020, 8, 418. [CrossRef]

69. Gligor, D.M.; Holcomb, M. The road to supply chain agility: An RBV perspective on the role of logistics capabilities. Int. J. Logist. Manag. 2014, 25, 160-179. [CrossRef]

70. Ganguly, A.; Nilchiani, R.; Farr, J.V. Evaluating agility in corporate enterprises. Int. J. Prod. Econ. 2009, 118, 410-423. [CrossRef]

71. Kumar, D.; Ramakrishna, H. Assessment of Supply Chain Agility Using Fuzzy Logic for a Manufacturing Organization; Social Science Research Network: Rochester, NY, USA, 2012.

72. Yang, S.L.; Li, T.F. Agility evaluation of mass customization product manufacturing. J. Mater. Process. Technol. 2002, 129, 640-644. [CrossRef]

73. Bottani, E. A fuzzy QFD approach to achieve agility. Int. J. Prod. Econ. 2009, 119, 380-391. [CrossRef]

74. Azevedo, S.; Prata, P.; Fazendeiro, P.; Cruz-Machado, V. Assessment of Supply Chain Agility in a Cloud Computing-based Framework. Scalable Comput. Pract. Exp. 2012, 13, 295-302.

75. Sanchez, L.M.; Nagi, R. A review of agile manufacturing systems. Int. J. Prod. Res. 2001, 39, 3561-3600. [CrossRef]

76. Chopra, S.; Meindl, P. Supply Chain Management. Strategy, Planning \& Operation. In Das Summa Summarum des Management: Die 25 wichtigsten Werke für Strategie, Führung und Veränderung; Boersch, C., Elschen, R., Eds.; Gabler: Wiesbaden, Germany, 2007; pp. 265-275. ISBN 978-3-8349-9320-5.

77. Sherehiy, B.; Karwowski, W.; Layer, J.K. A review of enterprise agility: Concepts, frameworks, and attributes. Int. J. Ind. Ergon. 2007, 37, 445-460. [CrossRef]

78. Conboy, K. Agility from First Principles: Reconstructing the Concept of Agility in Information Systems Development. Inf. Syst. Res. 2009, 20, 329-354. [CrossRef] 
79. Bernardes, E.S.; Hanna, M.D. A Theoretical Review of Flexibility, Agility and Responsiveness in the Operations Management Literature: Toward a Conceptual Definition of Customer Responsiveness. Available online: https://www.ingentaconnect.com/content/mcb/024/2009/00000029/00000001/art00002 (accessed on 25 April 2020).

80. Wu, C.; Barnes, D. A literature review of decision-making models and approaches for partner selection in agile supply chains. J. Purch. Supply Manag. 2011, 17, 256-274. [CrossRef]

81. Christopher, M. Logistics and Supply Chain Management: Creating Value-adding Networks, 4th ed.; Pearson Education Limited: London, UK, 2011; ISBN 978-0-273-73112-2.

(C) 2020 by the authors. Licensee MDPI, Basel, Switzerland. This article is an open access article distributed under the terms and conditions of the Creative Commons Attribution (CC BY) license (http://creativecommons.org/licenses/by/4.0/). 